\title{
On Two Metacercariae of the Genus Podocotyle from the Shrimp, Pandalus goniurus, from Aniwa Bay, Sakhalin, USSR (Trematoda: Opecoelidae)*
}

\author{
Takeshi SHIMAZU** \\ (Received January 13, 1973)
}

\begin{abstract}
From the shrimp, Pandalus goniurus, taken in Aniwa Bay, Sakhalin, USSR, two encysted digenean metacercariae were described.

One of them frequently occurred in the body muscles of the posterior cephalothorax region of the shrimp. It was found out to be the metacercaria of Podocotyle reflexa. Its experimentally induced infection to fish, Tribolodon hakonensis, met with failure. Some of the anatomical features observed were newly added to USPENSKAYA's (1963) description of the metacercaria of $P$. reflexa. The life-cycle of $P$. reflexa in Aniwa Bay was briefly discussed.

The other metacercaria was rarely found in the dorsal heart wall of the shrimp. It proved to be an unidentified Podocotyle species metacercaria. The well-developed metacercaria did not represent in the progenesis. In connection with the identification of the metacercaria, the species of Podocotyle which had been recorded from the northern Far-East seas were discussed.
\end{abstract}

In the course of the studies on the life-cycles of nematodes of the subfamily Anisakinae (Ascarididae), a survey of larval anisakid nematodes in the shrimp, Pandalus goniurus, was carried out in Aniwa Bay, Sakhalin, USSR, during 1970 to 1972. In the present survey, no nematode larvae but metacercariae of the two digenean species, Podocotyle reflexa and an unidentified Podocotyle species, were obtained from the shrimp.

In the present paper, these metacercariae are described and classified, and their brief life-cycles in Aniwa Bay are discussed.

\section{Materials and Methods}

The shrimp, Pandalus goniurus StimPson, was commercially caught chiefly from the area located between latitudes $45^{\circ} 50^{\prime}-46^{\circ} 00^{\prime} \mathrm{N}$ and longitudes $142^{\circ} 30^{\prime}-142^{\circ} 40^{\prime} \mathrm{E}$, at the depths between 75 and $90 \mathrm{~m}$, in Aniwa Bay, Sakhalin, USSR. During August to October 1970, several hundred formalin-preserved shrimps were dissected individually and examined for parasites with the necked eye. In November 1970 and August 1971 and 1972, a large number of fresh shrimps were examined in the same way.

The metacercariae were dissected out of the fresh shrimps, liberated from the cysts, flattened under the cover glass, fixed in $10 \%$ neutralized formalin or in ZENKER's solution,

* Supported in part by Grant in Aid for Developmental Scientific Research of the Ministry of Education in 1970.

** Faculty of Medicine, Shinshu University, Matsumoto, Nagano Prefecture, Japan （酎津 武：信 州大学医学部) 
stained with DELAFIELD's hematoxylin, dehydrated, cleared, and mounted in Canada balsam. Several blocks of the parasitized host tissues were fixed in ZENKER's solution, sectioned serially at $5 \mu$, stained with hematoxylin and eosin, and mounted in balsam. The excretory system was studied on some live metacercariae.

The experimental infection of the metacercaria to the fish, Tribolodon hakonensis (GUENTHER), was attempted several times in August 1972 as follows: Small blocks of the fresh shrimp's tissues containing many metacercarial cysts were forced into the upper expanded part of intestine of the fish with the aid of a glass pipette; the fish were killed and examined for worms 5 hours or one day later.

The formalin-preserved cysts and whole mounted worms were measured by means of a calibrated micrometer eye-piece. All measurements are given in millimeter. Drawings were made with the aid of a microscope projector or a camera lucida.

\section{Observations and Discussion}

\section{Metacercaria of Podocotyle reflexa (Opecoelidae)}

A large number of metacercariae were found in the body muscles of the posterior cephalothorax region of the shrimp. The incidence of infection was always very high. The intensity of infection varied from few to frequent innumerable cysts an infected shrimp. It was unable to follow exactly up the incidence and intensity of infection in the present survey, because it was difficult to detect all of the small encysted metacercariae from the shrimp's muscles with the necked eye. The histological sections of the parasitized shrimp muscles showed that the host cells aggregated to form a capsule around the metacercarial cyst wall. The capsule was pigmented brown and shaped irregularly. The experimental infection of metacercariae to $T$. hakonensis met with failure. Every worm inserted was discharged from the fish's digestive tract within 5 hours.

Description (based on 17 whole mounts; Figs. 1-3). Cyst elliptical, $0.22-0.28$ by 0.28-0.36 (based on ten cysts); cyst wall single layered, transparent, 0.004 thick. Metacercaria flattened dorso-ventrally in forebody and subcylindrical in hindbody, 0.38-0.68 long by $0.15-0.27$ wide; forebody $0.21-0.37$ long. Gland cells several in number, clustered laterally to posterior one-third of esophagus in each side of forebody, with a pair of bundled ducts opening dorsally at anterior tip of body. Cuticle smooth. Oral sucker 0.05-0.08 in diameter; prepharynx 0.01-0.02 long; pharynx heart-shaped, 0.02-0.04 in diameter; esophagus muscular, 0.04-0.12 long; intestinal ceca reaching near posterior extremity, joined to excretory vesicle with a tissue strand at posterior tips. Ventral sucker protrusive, $0.11-0.16$ wide by $0.10-0.16$ long; sucker ratio $1: 1.83-1: 2.50$. Testes tandem, subglobular, $0.05-0.08$ wide by $0.02-0.04$ long, located behind mid-level of hindbody; 
cirrus pouch club-shaped, about 0.07 long; seminal vesicle saccular, present in cirrus pouch; pars prostatica, prostate cells, and cirrus not distinct; genital pore located to left, at midlevel of esophagus. Ovary subglobular, $0.04-0.06$ wide by $0.01-0.03 \mathrm{long}$, situated in front of anterior testis; oviduct and ootype not yet differentiated distinctly, but their anlagen lying to left, in front of ovary; LAURER's canal not observed; uterus running forward directly. Vitellaria not yet differentiated. Excretory vesicle saccular, sometimes expanded largely in intercecal field, reaching ovary, lined internally with small epithelial cells; main excretory tubes ciliated, dividing into anterior and posterior collecting tubes at mid-level of ventral sucker; flame cell formula $2[(2+2)+(2+2)]=16$; pore subdorsoterminal.
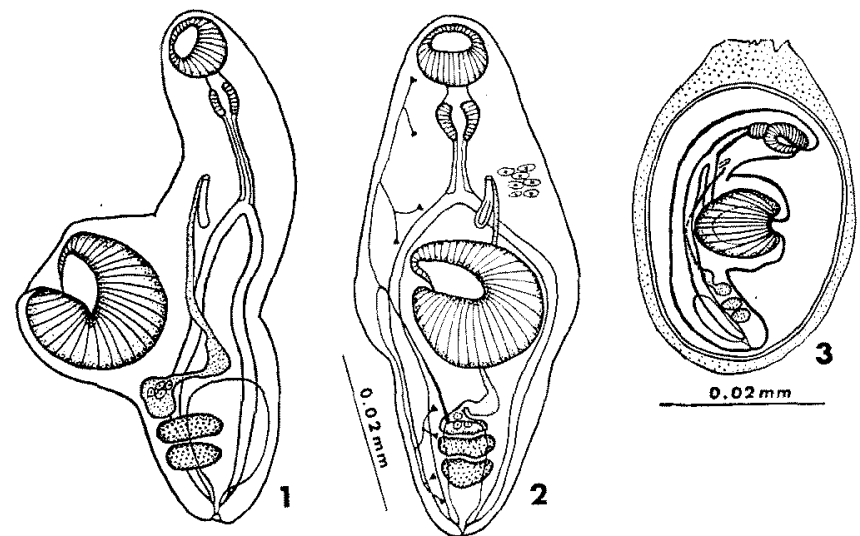

Figs. 1- 3. Metacercaria of Podocotyle reflexa from Pandalus goniurus. 1: Metacercaria liberated from cyst; lateral view. 2: Metacercaria; ventral view. 3: Cyst.

Discussion USPENSKAYA ${ }^{11}$ has already reported the metacercaria of Podocotyle reflexa (CREPLIN, 1825) ODHNER, 1905 from the muscles of six species of the benthic decapods including Pandalus borealis and $P$. annulicornis from the sublittoral zone in the Barents Sea. She attempted successfully to raise experimentally the metacercaria to the adult $P$. reflexa in the fish. The present metacercaria from Pandalus goniurus is closely similar to USPENSKAYA's description of that of $P$. reflexa in essential morphology and biology, except for having the more developed cirrus pouch. P. reflexa has been occasionally recorded from the various marine fishes in the northern Far-East seas. ${ }^{2-6)}$ In Aniwa Bay in November 1970, Theragra chalcogramma and Gadus macrocephalus were found to feed well on $P$. goniurus, and the adults of $P$. reflexa of different stages of development were obtained very commonly from these fishes and rarely from Lycodes schmidti and Eleginus gracilis (Shimazu, unpublished data).

For these reasons, the present metacercaria is most likely to be that of $P$. reflexa. Then, the following morphological observations of the present metacercaria should be added to UspenskayA's ones: (1) the pigmented capsule surrounding the metacer- 
carial cyst is composed of the aggregate cells from the host; (2) the metacercarial cyst measures 0.22 to 0.28 by 0.28 to $0.36 \mathrm{~mm}$ in size; (3) the short, club-shaped cirrus pouch with the saccular seminal vesicle in it is differentiated in the late stage of metacercarial development; (4) the anlagen of ootype-MeHus' glands complex, uterus, and metraterm lie between the ovary and genital pore; and (5) the flame cell formula is $2[(2+2)+(2+2)]$ $=16$. USPENSKAYA observed that $P$. reflexa remained sexually immature during the metacercarial stage in the decapod hosts. In the present survey as well, no mature metacercaria was obtained from $P$. goniurus. These results suggest that the metacercaria of $P$. reflexa may not represent the progenesis in the second intermediate host, unlike that of Podocotyle atomon. ${ }^{7,8)}$

In Aniwa Bay, $P$. reflexa would efficiently complete its life-cycle utilizing $P$. goniurus as the second intermediate host and such representative predators of $P$. goniurus as $T$. chalcogramma and G. macrocephalus as the common definitive hosts. The cercarial stage of this digenean is unknown up to now. The failure of the experimental infection of metacercariae to $T$. hakonensis appears to be due to the lacks of stomach and pyloric ceca in this fish.

\section{Metacercaria of an unidentified Podocotyle species (Opecoelidae)}

A small number of metacercariae were discovered in the dorsal heart wall of the shrimp. The incidence of infection was always very low, ranging from 0.4 to $1.7 \%$. The intensity of infection was low, varying from one to four metacercariae an infected shrimp. These facts made it difficult to collect live metacercariae from the shrimps sufficiently for the experimental infection of metacercariae to $T$. hakonensis. No remarkable histological change was observed in the infected heart of the shrimp, except for a light aggregation of the host's cells around the metacercarial cyst.

Description (based on five whole mounts; Figs. 4-7). Cyst round to subglobular, $0.41-0.52$ by $0.43-0.61$ (based on nine cysts); cyst wall single layered, transparent, $0.011-$ 0.023 thick. Metacercaria elongate-oval, flattened dorso-ventrally, 1.86-2.58 long by 0.39-0.54 wide; forebody $0.76-0.90$ long. Gland cells numerous, present in dorsal side of parenchyma in each side of forebody, with ducts opening at anterior tip of body. Cuticle smooth. Oral sucker $0.20-0.25$ wide by $0.18-0.21$ long; prepharynx $0.03-0.04$ long; pharynx barrel-shaped, 0.09 wide by $0.11-0.12$ long; esophagus muscular, $0.12-0.22$ long; intestinal ceca reaching near posterior extremity. Ventral sucker $0.35-0.41$ wide by $0.36-$ 0.38 long; sucker ratio $1: 1.65-1: 1.89$. Testes tandem, round to oval, $0.23-0.36$ wide by $0.17-0.26$ long, situated apart from each other in middle of hindbody; cirrus pouch club-shaped, 0.29-0.40 long, extending at most to mid-level of ventral sucker; seminal vesicle composed of proximal saccular part lined internally with large epithelial cells and distal tubular one with flat cells; cirrus and pars prostatica not distinct; prostate cells 
present in cirrus pouch; genital atrium shallow; genital pore situated to left, at slightly prebifurcal level. Ovary tri-lobed or irregular in outline, $0.16-0.21$ wide by $0.11-0.14$ long, located slightly to right, in front of anterior testis; oviduct ciliated, running firs left and then forward, and, immediately after receiving common vitelloduct, joining ootype; ootype preovarian, lying directed backward on left side of oviduct, on median line; MeHLIS' glands free in parenchyma; LAURER's canal opening dorsally to left intestinal cecum, swelling out in proximal part to form a seminal receptacle; uterus preovarian entirely, folded slightly; metraterm muscular; eggs not yet formed. Vitellaria follicular, extending continuously from mid-level of ventral sucker to posterior extremity. Excretory vesicle tubular, reaching ovary, lined internally with scattered small epithelial cells; main excretory tubes ciliated, dividing into anterior and posterior collecting tubes at level of ventral sucker; flame cell formula $2[(2+2)+2]=12$; pore terminal.

Discussion The present metacercaria also belongs to the genus Podocotyle in having the lobed ovary, the sinistral and prebifurcal genital pore, the tandem testes, and the vitellaria not extending into the forebody. From the northern Far-East seas, only two species of Podocotyle, P. atomon (RudolPhI, 1802) ODHNER, 1905 and P. reflexa, have been repeatedly recorded. ${ }^{2-6)}$ Besides these two, LAYMAN ${ }^{2}$ described Cainocreadium skrjabini from Azuma emmnion from Peter the Great Bay. YAMAGUI ${ }^{9}$ lately transferred this species from the genus Cainocreadium to Podocotyle. However, C. skrjabini may differ from any of the known Podocotyle species in possessing the spinose cuticle in the forebody, the dextral genital pore, the sinistral ovary, and the vitellaria arranged in the four longitudinal rows in the hindbody, so that this species should be excluded at least from Podocotyle.

In Aniwa Bay, the adult specimens of $P$. reflexa and an unidentified Podocotyle species were obtained from several species of the trawl-caught fishes in November 1970. The unidentified Podocotyle species was rarely found in the intestine of Limanda aspera, which was observed frequently to contain $P$. goniurus in its stomach. This digenean was characterized by having an elongate-oval and flattened body measuring 2.31 to $3.03 \mathrm{~mm}$ long by 0.48 to $0.82 \mathrm{~mm}$ wide, an esophagus almost twice as long as the pharynx, a sessile ventral sucker, a sucker ratio of $1: 1.47$ to $1: 1.78$, a short cirrus pouch extending at the most to the mid-level of ventral sucker, a tightly coiled seminal vesicle, a tri-lobed ovary, a preovarian uterus, and an unblocken vitellaria extending from the level of ventral sucker to the posterior extremity (SHImazu, unpublished data; Figs. 8-10). It could not be identified to species owing mainly to a small number of specimens obtained but differed at least from both $P$. atomon and $P$. reflexa in the above-mentioned morphology.

The present metacercaria is separated from the aforementioned metacercaria of $P$. reflexa by parasitizing the different habitat in the same shrimp host and by having the larger-sized cyst and body, the smaller sucker ratio, and the more developed reproductive 
organs as a whole. It can be also distinguished from the metacercaria of $P$. atomon by infesting the different habitat in the different host crustacean and by having the larger-sized body and internal organs, the shorter cirrus pouch, and the more numerous and dense vitelline follicles. The latter is encysted in the hemocoel of many littoral species of the
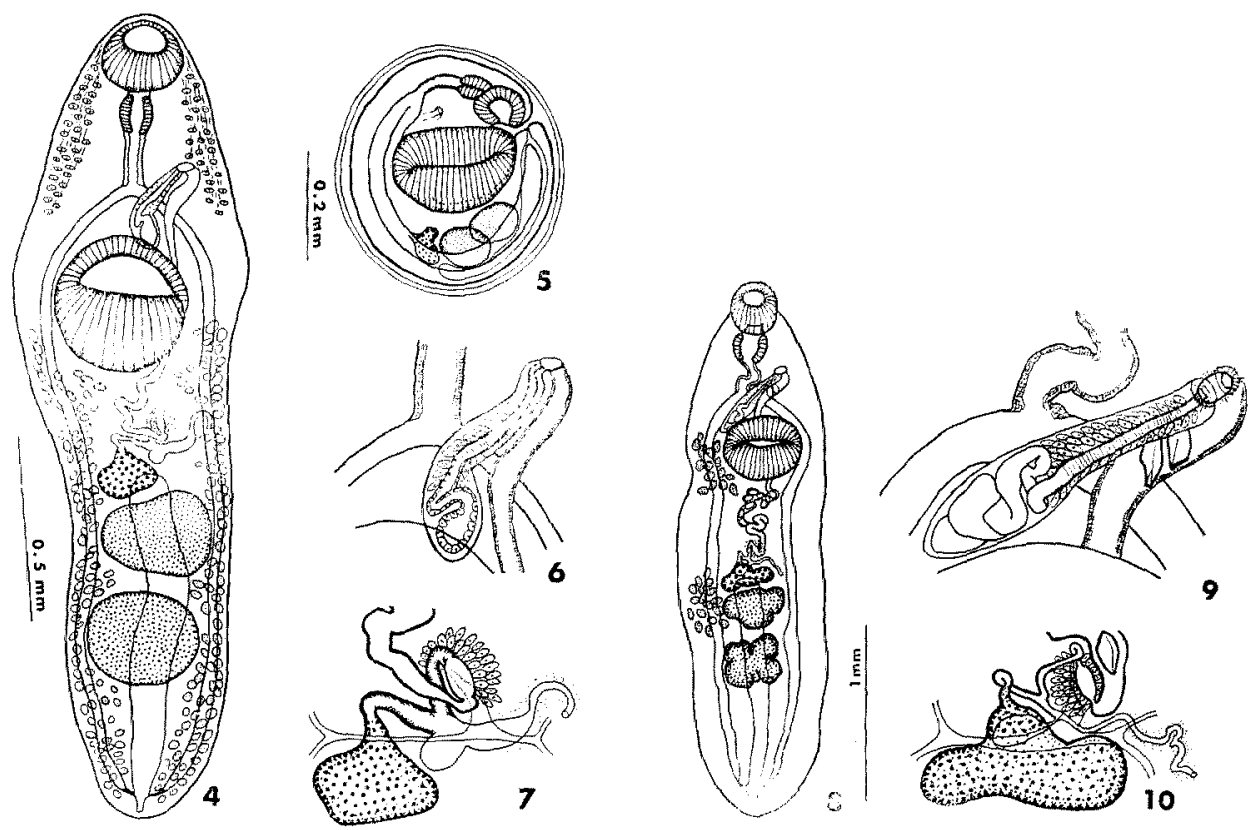

Figs. 4-7. Metacercaria of Podocotyle sp. from Pandalus goniurus. 4: Metacercaria liberated from cyst; ventral view. 5: Cyst. 6: Terminal genitalia; ventral view. 7: Reproductive organs; ventral view.

Figs. 8-10. Adult specimen of Podocotyle sp. from Limanda aspera. Vitellaria are not fully seen in this specimen. 8: Ventral view. 9: Terminal genitalia; ventral view. 10: Reproductive organs; ventral view.

marine amphipods, ${ }^{1,7,8,10,11)}$ isopod, ${ }^{11}$ and mysid. ${ }^{11}$ The present metacercaria probably differs from that of an unidentified Podocotyle species described by MACKENZIE and GIBSON $^{10)}$ in selecting the different species crustacean as the host, although the detailed description of the latter is not available. Thus, the present metacercaria may be different from the two hitherto recorded species of Podocotyle in the northern Far-East seas, and also from all of the hitherto described metacercariae of the genus.

The present metacercaria resembles the above-mentioned unidentified digenean from L. aspera in several anatomical respects but slightly differs from the latter in possessing the smaller pharynx, the slightly larger sucker ratio, and the more simple seminal vesicle. The simplicity of the seminal vesicle may be due to its less developed stage in the metacercaria. Nevertheless, it cannot be further discussed the relationship between them at 
present for lack of the experimental study of infection of the metacercaria to the fish. After all, the present metacercaria remains unidentified. In any case, the occurrences of these unidentified metacercaria and adult in Aniwa Bay indicate the need for the further research for the classification of the genus Podocotyle which occurs in the northern Far-East seas.

Although it had been well developed, the present metacercaria did not contain the eggs in its uterus. It is unknown at present whether the well-developed metacercaria represents the progenesis or not. Now, the flame cell formula of $2[(2+2)+2]=12$ in the present observation may be questionable, because that is $2[(2+2)+(2+2)]=16$ in the metacercariae of $P$. atomon ${ }^{7,8}$ and $P$. reflexa as previously mentioned. Accordingly, it requires to be confirmed in future.

I should like to express my gratitude to Mr. Yoshizumi ONODERA, Wakkanai, for providing me with the shrimp, and also to Messrs. Kenji ShibuYA and Kyoji Tomita, the Hokkaido Wakkanai Fisheries Experimental Station, for allowing me to use laboratory facilities at the station and for their various kindness during my visits there.

\section{References}

1) A. V. Uspenskaya: Parasite Fauna of Benthic Crustaceans from the Barents Sea, 127 pp., AN SSSR, Moskva and Leningrad (1963). (in Russian)

2) E. M. LAYMAN: Izvest. Tikhookeansk. Nauchno-Prom. Stantsii, 3, 1-120 (1930).

3) E. V. ZHukov: Trudy Zool. Inst. Akad. Nauk SSSR, 28, 3-146 (1960).

4) Yu. A. Strelkov: ibid., 28, 147-196 (1960).

5) E. S. SKruabina: Trudy Gel'mintol. Lab. Akad. Nauk SSSR, 13, 313-329 (1963).

6) M. Machida, J. Arak, H. KamiYa, and M. OHbayash: Mem. Nat. Sci. Mus., No. 5, 1-9 (1972). (in Japanese with English summary)

7) A. V. HunNinen and R. M. CABle: Trans. Amer. Microscop. Soc., 62, 57-68 (1943).

8) B. L. JAMES: 2. zool. Syst. Evolutionsforsch., 7, 273-316 (1969).

9) S. Yamagutr: Synopsis of Digenetic Trematodes of Vertebrates, Vol. 1, Ist ed., 1,074 pp., Keigaku Publishing, Tokyo (1971).

10) K. MacKenzie and D. I. Grbson: in "Symposia of the British Society for Parasitology. Aspects of Fish Parasitology" (A. E. R. TAYlor and R. Muller, eds.), Vol. 8, 1-42 (1970).

11) R. A. Shotter: Rep. Mar. Biol. Stat. Port Erin, No. 82, 35-37 (1970). 